Esta revista forma parte del acervo de la Biblioteca Jurídica Virtual del Instituto de Investigaciones Jurídicas de la UNAM juhttp://www.juridicas.unam.mx/

https://biblio.juridicas.unam.mx/bjv

https://revistas.juridicas.unam. $\mathrm{mx} /$

DOI: http://dx.doi.org/10.22201/iij.24485306e.2020.1.14814

NOTE

Universidad Nacional Autónoma de México, IIJ-BJV, 2020

https://revistas.juridicas.unam.mx/index.php/mexican-law-review/issue/archive 


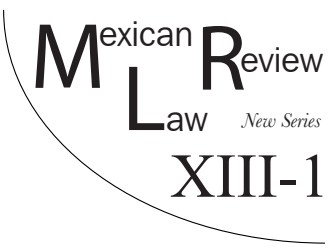

\title{
DRAFTING A CONSTITUTION IS NOT DRAFTING A STATUTE: AN ANALYSIS OF THE MEXICAN CONSTITUTION AND HYPER-AMENDING PATHOLOGIES FROM THE LEGISLATIVE DRAFTING PERSPEGTIVE
}

\author{
Jesús Manuel Orozco Pulido*
}

\begin{abstract}
This note critically examines the way the Mexican Constitution has changed since it was originally written, due to a large number of amendments. Through 239 decrees of constitutional reforms, which represent 732 modifications to constitutional articles, the current constitutional text is not the same document that arose from the Mexican Revolution. This vertiginous change is analyzed from the perspective of theoretical and practical notions of legislative drafting in common law countries. A huge number of reforms demonstrates a constitution's volatility, and the way reforms are written has a direct impact on whether or not it is observed. In fact, a proper process of redaction in legislative drafting can provide ideas for improving the quality of legislation. Reforming the constitution, as has been done by Mexican constituent powers, can overload the fundamental text with specific rules, rather than principles. An excessive use of words, an arbitrary use of subdivisions and an excessive number of transitory norms are common elements of constitutional amendments. Some specific traits of those amendments are analyzed in order to propose ways to improve the efficacy of the constitution through a better legislative drafting process for reforms. All of this in order to reach a better level of comprehension of the normative purpose of amendments by their final recipients: citizens and institutions.
\end{abstract}

Keywords: Mexican Constitution, legislative drafting, constitutional reform, legal efficacy.

RESUMEN: Esta nota critica la forma en que la constitución mexicana ha cambiado desde su texto original debido a un enorme número de reformas. A través de 239 decretos de reforma, que representan 732 modificaciones a sus artículos, la constitución actual no es el mismo texto que emanó de la revolución

* Attorney at law (University of Guadalajara) and Master in Parliamentary Procedures and Legislative Drafting (LUISS Guido Carli). Email: orozco.jesusmanuel@gmail.com. 
mexicana. Este cambio vertiginoso es analizado mediante herramientas teóricas $y$ prácticas de la redacción normativa que tienen bastante difusión en países del common law. Un gran número de reformas muestra la volatilidad de la constitución, y la forma en que tales reformas se redactan incide en la observancia. Por ello, la redacción normativa tiende a dar ideas para mejorar la calidad de la legislación a través de una adecuada escritura. La reforma de la constitución, como se ha hecho en México, versa en sobrecargar el texto fundamental de reglas, en lugar de principios. También es común observar una utilización excesiva de palabras, el uso arbitrario de subdivisiones y un número desorbitante de articulos transitorios. Algunas características en especifico son analizadas a fin de proponer ideas que mejoren la eficacia de la constitución por la vía de una mejor redacción normativa de sus reformas. El fondo de la cuestión es lograr una mejor comprensión del mensaje normativo por los destinatarios finales de la reforma: los ciudadanos y las instituciones.

Palabras clave: Constitución mexicana, redacción normativa, reforma constitucional, eficacia del Derecho.

\section{Table of Contents}

I. INTRODUCTION

II. Hyper-Amending Pathologies and the Mexican

Constitution.

III. Is the Mexican Constitution a Well Drafted Document? ..... 209

IV. Examples of Constitutional Profuseness.................................. 212

V. Future Scenarios .................................................................. 215

VI. Conclusions................................................................... 216

\section{INTRODUCTION}

A constitution is the cornerstone of a legal system: it is the origin of the state; it determines the validity of the rest of the norms of a legal system; it proclaims the fundamental rights to which citizens are entitled; and it provides a framework for the exercise and control of power. ${ }^{1}$ Scholars have studied constitutions from theoretical and practical viewpoints, using legal, political and sociological criteria. However, specialized literature has rarely analyzed constitutions as texts, particularly ignored is the way they are drafted.

The Mexican Constitution dates from 1917, it was an outcome of the Mexican Revolution. ${ }^{2}$ It is recognized worldwide for being one of the first

1 Eduardo García de Enterría, La Constitución como nORMa Y EL tribunal CONSTituCiOnal 49 (Civitas, Madrid, 1983).

2 Constitución Política de los Estados Unidos Mexicanos [Const.], as amended, Diario Oficial de la Federación [D.O.], 5 de febrero de 1917 (Mex.). 
constitutions that proclaimed social rights. However, the current constitutional text is not that similar to the original version, as a huge number of amendments have practically created a brand-new document. The main task of this note is to examine the way said amendments have an impact on the observance of the fundamental text.

In common law countries, the process of legislative drafting seeks to provide citizens with statutes that express normative purposes in the proper manner. Thus, the Mexican Constitution is examined here via the theoretical and practical tools proposed for legislative drafting. A crucial element of this analysis is connected to how the frequency of constitutional reforms and the particular way these reforms are drafted impact the observance of the magna carta.

\section{Hyper-Amending Pathologies and the Mexican Constitution}

The Mexican Constitution is one of the oldest constitutions in Latin America. No matter that this centenarian document is formally a rigid text - because the requirements for amending it are stricter than those for any other kind of legislation - in practice its rigidity has been banalized. Since its promulgation in 1917, the constitution has been amended by 239 decrees. The last reform considered in this note is the one published on August 9, 2019, regarding juridical recognition for Afro-Mexican communities. ${ }^{3}$ The huge number of amendments is an eloquent manner of showing the volatility of the constitutional text. The original text that emerged from the Mexican Revolution had just 21,000 words, whereas the current document has nearly three times as many. ${ }^{4}$

The 239 decrees of reform can imply more than one amendment to a particular Article of the constitution, as one decree usually involves more than one article. If the counting of amendments is focused on the number of Articles that have been modified, the quantity is shocking: the Mexican Constitution has been modified 732 times. Only 22 Articles remain as they were, without any amendments from the original text. ${ }^{5} \mathrm{~A}$ decree modifies a certain topic in the constitution, and the normative articulation of the reform implies a mix of additions, derogations and rephrasings.

3 Data obtained from Mexican Chamber of Deputies, where Mexican constitution is published with all its reforms, http://wrere.diputados.gob.mx/LeyesBiblio/index.htm. Also, it is considered the counting made in Héctor Fix Fierro et aL., Constitución Política de los Estados Unidos Mexicanos. Texto reordenado y consolidado 2 (UNAM, México) (2016).

4 Idem.

5 Mauro Rivera, Understanding Constitutional Amendments in Mexico: Perpetuum Mobile Constitution, IX Mexican Law Review, 3, 27, vol. IX (2017). 
The reform of the juridical regime of Mexico City, published on January 29, 2016, is a curious example. It modified 52 Articles of the constitution, which in numerical terms is equivalent to a third of the magna carta. The decree published on August 27, 2018, amended a transitory article of a previous constitutional amendment on February 10, 2014, in order to incorporate the new denomination of the Attorney's General Office to a previous electoral reform. The fact that constitutional reforms are passed in order to clarify a previous reform shows that there is little care to preserving the fundamental text.

Considering the huge number of times that Mexican Constitution has been amended - 239 decrees that contain 732 modifications to constitutional Articles - it is easy to see how the fundamental text is a normative product that easily adapts to the specific goals of the political class. Thus, the constitution adopts the shape that constituent powers want to give it according to particular circumstances. The ways and frequency with which it has been drafted over the last 100 years confirms this idea.

It is important to open a debate about how amendments to the constitution jeopardize compliance. In particular, it is necessary to consider that the way legislation is finally written - considering that a constitution is a legislative product that is also drafted - is related to the efficacy of norms, or in other words, their observance. Legislative drafting theories and practices shed more light on this issue.

Theoretical perspectives on legislative drafting enable a proper usage of normative documents. However, this is not an easy task. As Bowman stated, five different drafters will come up with five different bills, from this he concludes that legislative drafting is an art rather than a science. ${ }^{6}$ Indeed, a drafter has to be creative in order to translate in written, normative terms what exactly policy makers seek to achieve. When drafting such a crucial document the level of complexity increases, so writing a constitutional reform is not an easy task at all.

In order to facilitate drafting process, techniques have been developed, for example around plain language. Plain language permits norms to be written with precision, clarity and without ambiguity. ${ }^{7}$ For this purpose, there are golden rules to be considered, such as writing in the active voice, in the present tense, preferring shorter sentences rather than longer ones, careful wording, and using positive statements instead of negative ones. ${ }^{8}$ More specific tools, like flow charts, tables, indexes or explanatory notes, help to provide users of legislation with proper context so that they can appreciate the significance of what they read. ${ }^{9}$

6 Geoffrey Bowman, The art of legislative drafting, 7 European Journal of Law Reform, 3, 18 (2005).

7 Ruth Sullivan, The Promise of Plain Language Drafting, 47 MaGill Law Journal, 102, 103 (2001).

8 Geoffrey Bowman, The art of legislative drafting, op. cit.

9 Ruth Sullivan, The Promise of Plain Language Drafting, op. cit. 
The goal of legislative drafting is to make it easier to comply with the law. Some of those techniques should be applied to Mexican Constitution, which lacks efficacy. Its extended wording leads to miscomprehension and the excessive frequency of reforms does not allow for the cultivation of proper knowledge or application.

A constitution seeks to set guidelines for institutions as well as establish fundamental rights. It is important to write such key content in terms that are intelligible to all people. Regardless, the Mexican Constitution lacks a structure that allows for an easy identification of its basic traits, due to a hyperamending pathology. Regrettably, constitutional reforms have been written using a specific, thorough wording, that blurs the political principles set out in the magna carta. With its extended text and confusing terms, the Mexican Constitution runs contrary to the idea that a constitution is the recipient of essential principles that lead a nation.

Clarity in legislation facilitates the understanding of the message of the law. Nevertheless, when a legal clause involves refinements, conditions, exclusions and so forth, the application of law diminishes. ${ }^{10}$ In this sense, the Mexican Constitution lacks clarity, because its chapters are disorganized and its long, sprawling contents have become unintelligible due to the huge number of issues that are regulated with specificity, rather than regulated in a more general fashion.

The first chapter of the Mexican Constitution has a title referring to human rights and guarantees. However, within this chapter there are specific regulations about nine autonomous organizations that carry out activities outside of the umbrella of human rights, including: public universities, evaluation of education, governmental transparency and data protection, official statistics, social development, agrarian courts, national banking, economic competence, and telecommunications. In addition, other fundamental rights are contained outside this first chapter, such as labor rights established in Article 123. Moreover, guarantees for human rights are not even mentioned in the first chapter, much less regulated, contrary to the title. These guarantees - procedures on electoral jurisdiction, writ of amparo, constitutional controversies and actions of unconstitutionality - are regulated on Articles 99, 103, 105 and 107.

Sullivan identified a common problem with legislation, as it is drafted in long, convoluted sentences and relies on obscure jargon. ${ }^{11}$ A crucial task of a democratic state is to make the constitution an effective document. The work of the drafters is to improve the quality of legislation. These approaches should be mixed in order to enhance the quality, and therefore the efficacy, of the fundamental text.

The manner of writing a legal document is an urgent task for common law countries, which are pioneering the creation of academic programs that

10 Francis Bennion, The Readership of Legal Texts, 27 Clarity, 18 (1993).

11 Ruth Sullivan, The Promise of Plain Language Drafting, cit. 100. 
train professional drafters, ${ }^{12}$ establishing specific units of government lawyers specialized in drafting, ${ }^{13}$ or launching specialized literature on the issue.

However, the drafting of legislation in civil law countries is just beginning to take its first steps. In Mexico, constitutional studies are usually conducted for prescriptive or commemorative purposes, rather than for practical analysis. ${ }^{14}$ It is necessary to regard the constitution as a pragmatic document in order that it should have sufficient quality.

Real political change is camouflaged behind the hyper-amending pathology of the Mexican Constitution. In order to create the perception that the increase of constitutional clauses is just a reform and not a brand-new document, the number of articles remains the same, which is 136 . However, the specific content of those constitutional articles has vertiginously changed, as it is shown by its 239 amendment decrees, which contain 732 amendments to constitutional articles.

For instance, a decree published on January 29, 2016 gave birth to Mexico City as a geopolitical subnational entity, derogating its status as a Federal District. This reform modified 52 constitutional articles, mostly changing the words referring to the Federal District.

In fact, approximately 84 per cent of the original version of 1917 Constitution has been modified and the constitution is subject to a permanent change. ${ }^{15}$ From a practical and materialist viewpoint, the Mexican Constitution is not the same document that arose from the Revolution at the beginning of XX century. Although a developing country needs its foundational document to be up to the date, multiplying reforms damages its efficacy instead of enhancing it, because citizens and institutions no longer comprehend its meaning. Another negative effect is that politicians develop the idea that the constitution is not a barrier for avoiding excesses of power. Rather, it appears as an obstacle that is easy to remove through an amendment.

Upon closer examination, other deficiencies emerge. The fact that the constitution is written in complex, long winded sentences, and that a single reform usually involves several Articles, makes almost impossible to follow which constitutional norms are valid in a particular moment in time.

It is common to use vacation legis norms in order to leave a period of time in order to implement a reform. However, the Mexican Constitution sets out a complex variety of deadlines, so in the same reform there can be different dates for the entry into force, depending on the specific issue that is regulated.

12 For instance, the Institute of Advanced Legal Studies (SAS-University of London) offers LLM courses, clinics and summer programs specifically related to legislative drafting issues.

13 Office of the Parliamentary Counsel, 85, Drafting Guidance (2017).

14 Raymundo García García, Del institucionalismo histórico al neoinstitucionalismo en la docencia e investigación del constitucionalismo mexicano, in Constitucionalismo. Dos Siglos De SU Nacimiento en América Latina 3, 22 (César Astudillo ed., UNAM, Mexico) (2013).

15 Mauro Rivera, Understanding Constitutional Amendments in Mexico: Perpetuum Mobile Constitution, cit. 
This complex regulation leads to confusion and does not set a definite time period for when a reform must be fully implemented. This is a hidden effect of constitutional mobility, since the constitutional order is regularly transformed by the final provisions of each decree.

In addition, transitory norms in decrees are excessive and create an unnecessary parallel context for the implementation of constitutional reforms. For instance, the original constitution of February $5^{\text {th }}$, 1917, had only nineteen transitory articles. Considering that the constitution was written during a transitional period following a revolution, this seems to be a coherent number.

Nowadays there is a trend towards maximizing the use of transitory articles in order to reinforce the implementation of reforms. More than just considering the time for the entry into force of the reform, or a derogatory provision, in Mexico transitory articles of constitutional reform decrees also specify rules for the appointment of high level officers and other detailed provisions that would be better developed in secondary legislation.

For instance, the government transparency reform published on February 7th, 2014, foresees in transitory articles a complete calendar for the replacement of each public official of the transparency institute. The political reform of February $10^{\text {th }}, 2014$, has twenty one transitory articles that foresee a wide variety of rules, including the contents of basic norms that shall be developed by secondary legislation. These are normative requirements that would be properly foreseen in the constitution and not in transitory articles. The education reform of May 15th, 2019, includes eighteen transitory articles and sets complex rules related to the contents and implementation of the reform.

Constituent powers for amending the constitution, which involves the national Congress and subnational legislative assemblies, should only be implemented for core topics. There should be space for secondary legislation, so that as legislatures develop constitutional clauses, the constitution does not become a catch-all, but just the point of reference.

Besides its legal implications, the large number of reforms creates a social perception that amending the constitution is as simple as creating another piece of legislation. If the constitution is not a thick barrier that protects the empire of law, it becomes just another layer that is easily removed.

\section{Is the Mexican Constitution a well DRaFted document?}

A constitution is supposed to guarantee the basic needs of the State and its inhabitants. Constitutional clauses should be constantly exercised by their final receivers: citizens and institutions. If a constitution is only reserved for a political and legal elite, the link between a people and their fundamental document is broken. Regrettably, this is the case of Mexican Constitution.

People need to know what fundamental rights they are entitled to their welfare, and which limits exist for controlling power. When constitutional 
knowledge is lacking, any infringement to the legal order might become banalized and citizen interest in pursuing their rights would diminish.

Overloading a constitution with ambitious rights or brand new institutional models that are unreachable also leads to the inobservance. ${ }^{16}$ If there is a lack of means to meet requirements, a constitution becomes nothing more than an aspirational document that agglutinates the best desires of the state, but it is not considered a real norm to be respected and of which inobservance implies an abdication of responsibilities.

If the constitution is merely a symbolic document with hollow clauses and contents, it will become a dead letter, no matter the effort made by a constitutional assembly to draft it. In fact, according to Latinobarometer, Mexico is the Latin American country in which citizens have the poorest level of attachment with the law, and where behaviors are guided by self-consciousness rather that by norms. ${ }^{17}$

Legal philosopher Nino described anomia as a predisposition for not respecting norms, showing a lack of interest to fulfill the democratic aspirations enshrined in the rule of law. ${ }^{18}$ Constitutional anomia is a common phenomena in Mexico. The constitution is there, everybody sees it, but its principles and rules are not observed. Part of the problem is related to the overloading of contents of the fundamental text, and another part is that no drafter took a pause in order to better write the reforms.

Efficacy of law, understood as the quality of norms to meet goals to such a degree that judicial interpretation is not necessary, ${ }^{19}$ is a common, contemporary concern in law. Plenty of new legislation is passed each year in parliaments and congresses in Mexico, but the general situation is not encouraging at all.

According to Jones, the lack of means for communicating the law's message minimize its enforcement. ${ }^{20}$ This factor also emerges when studying the situation of the Mexican Constitution. After the enormous number of amendments, not even the average lawyer is aware of what specific contents are enshrined in the highest norm. Because of this, some arrangements should be made.

Common law tradition has been built on the basis of legal precedents dictated by courts, but these are not the only source of law. Acts and statutes

16 Giovanni Sartori, Ingeniería constitucional comparada. Una inVESTigación de esTructuras, incentivos y Resultados, (Fondo de Cultura Económica, 2a. ed., México, 2001) (1994).

17 Latinobarómetro, Informe Latinobarómetro 2018, https:///C:/Users/HP/Downloads/INFOR ME_2018_LATINOBAROMETRO.pdf.

18 Carlos Nino, Un país al margen de la ley, (Ariel, Buenos Aires, 2014) (1992).

19 Helen Xanthaki, On Transferability of Legislative Solutions: The Functionality Test, in DrafTING Legislation, A Modern Approach 5 (Routledge, London, 2016).

20 Harry W. Jones, The Efficacy of the Law, 18, 20, 32, 34 (Northwestern University Press) (1969). 
passed by a parliament or a congress provide the general legal framework, and then the final receivers of law have to find precedents that provide a concrete solution to a given case. It is common practice for a legal addressee to carry out a paper chase of relevant legal material that provide him or her with existing statutory law and updated precedents. ${ }^{21}$ Internationally, parliaments have even begun putting in practice a consolidation of legal systems in order to organize all the rules on a specific area in a single document.

The point of these efforts is not necessarily to codify a particular branch of law, as doing so would require the creation of new legislation. ${ }^{22}$ Rather, consolidation prevents people from getting lost in the legal system when they are trying to find relevant provisions. Consolidation enables easier access to justice. ${ }^{23} \mathrm{~A}$ similar exercise should be emulated in the Mexican constitutional context. Some steps have been taken in this regard, such as procedural rules on criminal, civil and family trials that are now regulated by federal Congress through a national code, as was foreseen by constitutional reforms published on June 18, 2008 and September 15, 2017.

It is not even clear what the structure of the constitution is. Traditionally, each constitutional article is divided into paragraphs, each of which sets up one idea for a regulatory purpose. Parts are then used in order to enumerate (with roman numerals, starting with I, and so forth) more detailed norms, for example Articles 31, 55 and 107.

As the details of a regulation proceed, incises with lower letters are used, starting with a), and so on, such as Article 105. When the same article regulates a variety of topics, it is usually divided into sections divided by capitalized letters from A to Z. This is the case of Article 102, which paradoxically in section A regulates the Attorney General's Office and in section B regulates the Ombudsman.

The drafters of Mexican Constitution have used a variety of forms to divide a single article, without following the same criteria. A paradigmatic example is Article 41, a catch-all article that is also one of the lengthiest, that mixes parts, sections and incises. Article 72 introduced an arbitrary division in sections with capital letters rather than with fractions with roman numerals, as tradition would have it.

Drafters of the Decree of February 10, 1949, likewise, introduced a peculiar division using parts, numbers and incises, all of them arbitrarily appearing in the same constitutional article. The same defect is present in Article 123, which most peculiar regulation is on part XXIX, incise a), numbers 1 to 22. This complex regulation foresees the federal jurisdiction for labor trials related to certain industrial activities.

21 Alec Samuel, Consolidation: A plea, 26 Statute Law Review, 59, Oxford University Press (2005).

22 Idem.

23 Patricia Rickard-Clarke, Access to justice: accessibility, Statute Law Review 159, 164, Oxford University Press (2011). 
Returning to the thrust of this article, we see that the Mexican Constitution has been drafted without attention to a precious rule of normative drafting: concreteness and organization. Moreover, the constitution contains absurd clauses that should be derogated, as they would fit better within secondary legislation.

For instance, Article 47 defines the territorial borders of Nayarit, a subnational state. Article 28 regulates the procedure for choosing commissioners of autonomous regulatory organizations with profuse explicitness. Article 41 regulates the number of minutes of TV advertising that should be allocated to political parties. A reform published on June 17, 2014, foresees a fourth transitory article establishing that the Ministry of Government has the duty to transfer death certificates to the National Electoral Institute. Adding meaningless norms overloads the constitution, negatively impacting comprehension and taking away from the importance of the magna carta.

When Legislative power amends the legal system, there is an aspiration to create a better context, so the norms approved have a positive impact on society. It is crucial that a new approach for reforming the Mexican Constitution be adopted, cutting excessive wording that debilitates the final regulatory message. Instead, short, concrete principles and specific basic rules must be included in the constitution, giving it a heavier weight in legal culture.

\section{Examples of Constitutional Profuseness}

On the eve of the centenary commemoration of Mexican Constitution, a commission formed by renowned scholars revisited the constitution in order to propose technical improvements. ${ }^{24}$ The goal was to produce a coherent and accessible document, and not a compendium of specific regulations that should be contained in a secondary norms. This work should continue.

We can find many examples of overregulation in the federal system. Today, Mexican federalism in the constitution is blurred, in part because central government has absorbed almost all relevant attributions. The allocation of competences in Mexico works such that specific attributions in the constitution belong to the federal scheme, while those that are unwritten belong to the subnational entities. Article 73 foresees competences that yield the scope of federal power, while Article 124 establishes a residual clause through which subnational states assume competences that are not expressly conferred to the federation.

In the original text of the 1917 Constitution, Article 73 had thirty subsections which listed the subjects that are the exclusive competence of the national Congress. Today, the number of parts remains the same. However, Part

24 This Commission was led by renowned professors Diego Valadés and Héctor Fix, both from UNAM. 
XXIX of Article 73 has dramatically expanded - and the same phenomenon has occurred in Article 4, which has absorbed almost all the reforms related with social or economic rights-. The original version of Article 73, part XXIX, had subheadings from XXIX-A to XXIX-H, today the list of subheadings reaches XXIX-Z. Since there are no more letters available to be used in this subsection, another constitutional space will need to be found to hold future centralistic amendments. At the end of the day, as stated before, roman or arabic numerals, incises, or letters are arbitrarily used in the constitution.

From the perspective of legislative drafting, it would be better to create a specific article in the constitution that describes the centralistic traits of government, rather than increasing the attributions of federal power in a section which was originally limited to the core functions of the state. Considering that form and content are intrinsically connected, drafters have to deal with the content of legislation in order to find appropriate words to communicate the political message they wish to convey. ${ }^{25}$

A contemporary complaint in Mexican constitutionalism is that federal system is but a reminiscence of the origins of the republic, but in practice, the government is highly centralized. ${ }^{26}$ It is childish to think that only reforms to the constitution have a direct impact on the efficiency of laws. It is also necessary to define transversal policies and budgets in order to achieve goals.

A similar phenomenon took place during the constitutional reform of June 18, 2008 which introduced a new model of criminal justice. So far constitutional reform has not been an effective method of transforming the justice system, because the practices of prosecutors, barristers and the judiciary remain the same. Constitutional reforms in Mexico lack pragmatic, political and budgetary schemes that enable proper implementation. Those trying to apply the constitution are walking blind when trying to meet the objectives of reforms.

Another example is the reform published on August 24th, 2009, which modified Article 127 in order to create a threshold for salaries in public service, ensuring no public servant could earn more than the President of the Republic. Said reform established a vacation legis period of six months in order to create and harmonize secondary legislation with constitutional amendments. However, it wasn't until 2018 that secondary legislation was approved (Federal Act for Remunerations of Public Officials), which was challenged before the Supreme Court by senators and the national Ombudsman. ${ }^{27}$ Judicial review of this legislation provoked a challenging encounter between the

25 Ann Seidman et al., Legislative Drafting for Democratic Social Change: A ManuAL FOR DRAFTERs, 26 (Kluwer Law International) (2011).

26 José María SERna, El sistema federal mexicano. Un análisis Jurídico (UNAM, México) (2008).

27 Actions of unconstitutionality 105/2018 and 108/2018, ruled on May 20th, 2019. Pleno de la Suprema Gorte de Justicia de la Nación [S.C.J.N.] [Supreme Court]. 
Morena party and Supreme Court justices. Also, more than twenty thousand of individual writs of amparo lodged by public servants challenged that federal act.

Besides specific arguments regarding the scrutiny of secondary legislation, this problem could have been prevented if constitutional reform of 2009 had been sufficiently expanded and explained. What was needed was in fact a profound social and political debate on the limits of salaries paid to public servants. Congress failed to respect deadlines set in the constitution for the timely approval of complementary legislation. Both elements were absent, and by the time legislation related to the constitutional clause was published, the resulting debate was shockingly misunderstood. There are lessons should be learned from this experience.

According to Hunt, ${ }^{28}$ when amending legislation, an opportunity for updating the language contained within it arises. This was taken in mind on June 10, 2011 in the reform that renamed first chapter of the constitution, so it refers to human rights instead of individual guarantees. Adapting a name concordant with contemporary terminology has its merits. But if the real political aim was to make human rights a point of reference for all Mexican authorities, it would have been better to re-accommodate human rights into one chapter and remove topics that have no relation on it.

Mexico does not have a tradition of writing preambles in legislation. So the constitution lacks a foreword that facilitates a popular understanding of its magna carta. In other legal systems, when trying to identify the real meaning of a statute, it is common to analyze the travaux préparatoires, such as the original draft of the bill, legislative debates, and legal reports prepared by commissions from both chambers of congress. ${ }^{29}$ Regrettably, when a reform is published there is a lack of information for the debates that are held in Congress.

Interpreting what a constitutional assembly was aiming to achieve is technical and complicated work. Interpreting the constitution requires methods that are not the same as those used for interpreting ordinary legislation. ${ }^{30}$ Judges, lawyers, members of Congress and citizens should not conduct the interpretation of the constitution with exegetic techniques, or by literal or systemic methods. Interpreting the constitution requires putting its clauses under a microscope in order to understand details, and then zooming out to see what practical consequences the constitutional assembly wanted to achieve.

28 Brian Hunt, Plain Language in Legislative Drafting: Is it Really the Answer? 23 OXFord UNIversity PRess, 24, 46 (2002).

29 Timothy J Arnold-Moore, Point-in-time publication of legislation (XML and legislation) Automating Consolidation of Amendments to Legislation in Common Law and Civil Law Jurisdictions, JourneE INTERNET POUR LE DROIT (2004), http://wrerr:frlii.org/spip.php?article67.

30 Riccardo Guastini, Estudios sobre la interpretación jurídica (Marina Gascón trans., UNAM, 5d ed., 2003) (1999). 
Interpreting statutes and bills is a task carried out by judges, who need to be trusted by citizens and institutions in order to act with legitimacy and increase the efficiency of their rulings. ${ }^{31}$ In countries such as the United States, judges have played a key role in the struggle for rights. ${ }^{32}$ It is crucial to have a well drafted constitution that allows brave interpretations, especially interpretations made by Supreme Court.

Concreteness on constitutional clauses enhances argumentation in courts, as when the message of the law is circumscribed within few words, constitutional judges tend to maximize and deepen the reach of the norm. On the contrary, when a constitutional clause is profuse and thorough, the message of the law is banalized, leaving little space for judicial creation, or even imagination. This argument is supported by observing the huge number of judicial precedents that have emerged around Article 16 of the Mexican Constitution, which stipulates that all activities of the state must be based on law and motivated by facts. The same thing occurs with Article 103, in which three parts establish the writ of amparo as a guarantee that allows citizens to defend their fundamental rights.

Those plain, concrete constitutional messages have been interpreted by high courts enough to determine what aspects fall under the umbrella of concrete constitutional exigencies. The same effect occurs with citizens, who have but a general picture or even repeat from memory what the constitution means in their daily life. A kind of day-to-day reaffirmation of the constitution emerges, because the fundamental text actually serves for solving public struggles.

\section{Future Scenarios}

When the ship of the rule of law is sinking, as is happening in Mexico, it could be thought that the constitution is the only passenger who will remain afloat. It is necessary to enshrine all political agreements into the constitution, so that compliance becomes stricter. Nevertheless, it is paradoxical that instead of putting in efforts to improve implementation and compliance of secondary legislation, the problem of non-observance is transferred from regular legislation to the constitution. ${ }^{33}$

It appears that this phenomenon will not end, as the trend of governing and legislating from the constitution is presented as a solution. Over the last

31 Francis Bennion, Legislative Technique, The Science of Interpretation, 130 New Law Journals, 493 (1980).

32 Martin Shapiro, Revisión judicial en democracias desarrolladas, in Tribunales Constitucionales y Democracia 233, 262 (SCJN, México) (2010).

33 According to De Benedetto, ineffectiveness of law is usually transferred to micro towards macro scenarios. Maria De Benedetto, Why do we need effective law? Keynote address at the Institute of Advanced Legal Studies of the University of London (July 7th, 2017). 
three presidential administrations, the percentage of global constitutional amendments has increased enormously. Under the administration of President Felipe Calderón, 38 amendment were approved, President Peña Nieto passed 28, and 6 have been adopted in the first year of President Lopez Obrador's administration. ${ }^{34}$

Some constitutional reforms require extensive secondary legislation, as with criminal justice or technical subjects such as energy or telecommunications. Professional drafters argue that the quality of legislation decreases when rushing deliberative processes which are not clear enough. ${ }^{35}$

The same holes can be observed in the amending process, in terms of the automatic approval of constitutional reform by subnational congresses. No discussions or debates are triggered in order to justify why a subnational State has given its approval to a federal constitutional reform. It appears as just another procedural trait: after the national Congress approves the reform, each local congress automatically ratifies the core decision. In terms of the quality of legislation, no process is conducted by which local congresses bring the specific contents that were approved in the constitutional reform into their local sphere. A lack of empathy between reforms and their final receivers is repeated because there is no socialization of constitutional reforms.

\section{Conclusions}

If a constitutional culture is not properly disseminated, the possibility for the abuse of power increases. One step forward to strengthening the constitution is to draft it properly, in order to make messages of law clearer. Mexico has a hyper-amending pathology that shows no signs of recovery. At some point, this process will end up with a either a brand-new constitution or with a reorganization of the current text.

It is time to open the debate as to how to draft future amendments. The shorter constitutional amendments are when they are drafted, the more effective they will be, as more chances will be given to secondary legislation and courts to develop the rule of law based on strong constitutional principles.

There are lessons to be learned from studies of legislative drafting in the tradition of common law. Concreteness and assertiveness are elements that have been forgotten in drafting Mexican Constitution. It is past time to neutralize this hyper-amending tendency, and to recover the idea that a constitution is not just a regular statute. A constitution should not contain the minute details of legal systems, rather its core principles.

34 Héctor Fix Fierro et al., Constitución política de los estados unidos mexicanos.

TeXto REORDENADO Y CONSOLIDADO, cit.

35 Victoria Nourse \& Jane Schacter, The Politics of Legislative Drafting: A Congressional Case Study, 77 New York University Law Review, 575, 624 (2002). 
Esta revista forma parte del acervo de la Biblioteca Jurídica Virtual del Instituto de Investigaciones Jurídicas de la UNAM

Legislative drafting practices from common law traditions can provide Mexican constituent powers with tools to help them to create better legislation, including a better constitution. The process of writing an act, socializing its contents, and publishing the preparatory working material of legislative process, would produce a higher quality constitutional text. The easier to understand a written norm is, the more probable it is that it will be complied with. 